\title{
Implementation of building construction permit in So'e city, South Timor Tengah regency (TTS)
}

Misraim Nubatonis ${ }^{1}$, Petrus Kase ${ }^{2}$, Nursalam ${ }^{3}$

The Elections Supervisory Agency (Bawaslu) of Timor Tengah Selatan Regency, Indonesia ${ }^{1}$

Department of Administrative Science, Nusa Cendana University, Kupang, Indonesia ${ }^{2,3}$

misraimnubatonis@gmail.com

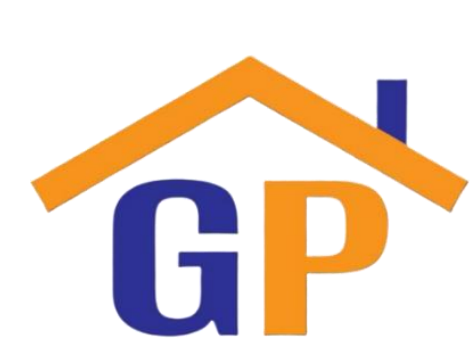

Article History

Received on 11 December 2020

Revised on 5 January 2021

Accepted on 12 January 2021

\begin{abstract}
Purpose: This study aimed to analyze the implementation of the Building Construction Permit policy and to analyze the inhibiting factors for implementing the Building Construction Permit policy based on the Regional Regulation of South Timor Tengah regency Number 7 of 2015 in So'e city, South Timor Tengah regency.
\end{abstract}

Research methodology: This research was qualitative research using a descriptive approach. The data were collected through interviews, observation and documentation.

Results: The inhibiting factor for the implementation of the Building Construction Permit policy in So'e city, South Timor Tengah regency is the limited resources in the form of human resources, financial resources, operational resources, buildings that are not in accordance with spatial planning and many buildings that violate the boundary lines as well as public understanding of building permit regulations.

Limitations: This study only analyzed the implementation of the Building Construction Permit policy based on the Regional Regulation of South Timor Tengah regency Number 7 of 2015 in So'e city, South Timor Tengah regency.

Contribution: This research becomes scientific information for public administration program.

Keywords: Implementation, Policies, Building permits

How to cite: Nubatonis, M., Kase, P., \& Nursalam. (2021). Implementation of building construction permit in So'e city, South Timor Tengah regency (TTS). Journal of Governance and Accountability Studies, 1(2), 103-119.

\section{Introduction}

So'e city is the capital of South-Central Timor (TTS) Regency with an area of $198.65 \mathrm{Km}^{2}$. So'e City has 11 (eleven) sub-districts and 2 (two) villages, with a population of 41,254 people, household (RT) 8,297 , area per family $28.08 \mathrm{Km}^{2} /$ person and population density reaching 1.451 people $/ \mathrm{km}^{2}$ (Badan Pusat Statistik Timor Tengah Selatan, 2018). In accordance with the Regional Regulation of TTS Regency Number 7 of 2015 concerning Buildings, it is stated in the provisions of Article 1 number 29 that "Building Construction Permits (IMB) are permits granted by the Regional Government to persons or legal entities to construct buildings, work constructing a building wholly or partly either constructing a new building or adding, changing, rehabilitating and/or repairing existing buildings, including excavating, stockpiling or levelling land related to the building construction work". Of course, regional regulation No.7/2015 applies not only to the So'e city but also to the entire TTS Regency area.

Furthermore, according to Article 9 paragraph (1) Regional Regulation No. 7 of 2015 concerning Buildings regulates that "Every building must meet the administrative requirements as regulated in the Legislation concerning Buildings which include: a. status of land rights and/or utilization permits from holders of land rights; b. building ownership status; and c. Building Construction Permit (IMB)". On average, community members build without fulfilling the conditions stipulated in Article 
9 of the regional regulation. However, the existing regional regulation is only limited to rights, so that residents do not need to rush to fulfil it.

In the provisions of Article 12 paragraph (1) of Regional Regulation No. 7 of 2015, it states that "(1) IMB is a proof letter from the Regional Government that the building owner can erect a building in accordance with the technical building plan approved by the Regional Government. (2) IMB is intended to control the construction and utilization of buildings in regional areas to ensure the safety of residents and the environment and orderly development. (3) Before erecting a building in a regional area, persons, bodies/institutions are required to submit a request to the Regent to obtain an IMB". This means that the provisions of this article require that each building be built according to its utilization and allotment. Besides that, there is income for the community and subsequently becomes regional income by paying a certain amount of money as a retribution payment for the TTS Regency area.

The procedure for filing a Building Construction Permit Application (PIMB) is regulated in Article 48 of the Regional Regulation Number 7 of 2015 concerning Buildings, that "Before submitting a PIMB, the applicant must ask for information about planning directions free of charge to the technical agency in charge of Regional Development Planning or the agency that handles licensing, namely city planning/building layout which includes: a. type/designation of buildings; $b$. permitted building floor area; c. the number of floors/layers of buildings above/below the ground level permitted by the applicable demarcation line; d. Permitted Green Area Coefficient (KDB); e. Building Floor Coefficient (KLB); f. Basic Building Coefficient (KDH); g. city utility networks such as electricity networks, telephone networks, drinking water networks, gas networks and so on; $h$. certain requirements for areas prone to earthquakes, floods, landslides and/or contaminated locations; and i. other requirements determined by the competent authority". Of course, this provision requires that the buildings to be built be adjusted to regional spatial planning in TTS Regency, but what happens is that residents always build without preceding it with regional spatial planning.

Regional Regulation No. 7 of 2015 concerning Buildings, in the provisions of Article 49 paragraph (3) stipulates that "IMB applications must be accompanied by: a. image situation; b. building plan drawings; c. calculation of structures for multi-store buildings (more than floors); d. advice issued from technical institutions based on recommendations. Head of District by observing a certificate from the Village Head or Head of Village; e. copy or photocopy of proof of land ownership; f. landowner permit approval for buildings erected on land that does not belong to him; g. copy or photocopy of proof of Land and Building Tax settlement for the current year; and h. copy/photocopy of the relevant Identity Card which is valid". On average, the buildings constructed do not meet the requirements stipulated in the regional regulations, so it is not easy to apply for an IMB

The firmness in Regional regulation No.7 of 2015 concerning Buildings is regulated in Article 54, namely that "It is prohibited to build buildings for anyone if: a. does not have an IMB; b. deviating from the provisions or further conditions of the IMB; c. deviates from the development plan which is the basis for granting IMB; d. deviates from the rules and conditions stipulated in the Legislation; and e. constructing a building on someone else's land without the owner's permission or legal proxies". However, the TTS Regency government has not maximally enforced the strictness of the regulation of Regional Regulation No.7 of 2015 so that the average IMB has not been taken care of by every building owner, both public and individual.

In accordance with the standard operating procedure (SOP), Building Construction Permits (IMB) are intended for individuals or legal entities who wish to build buildings in TTS Regency. While the objects include: (1). Building (private, general public, and government), (2). Fence; (3). Tower, (4). Gas stations, and (5). Billboards. All building permits are valid only as long as the building stands and there is no change in function, shape, area or type of construction. By having to complete the following requirements:

a. Fill out and sign the application form

b. Photocopy of ID card 
c. Photocopy of room recommendation (advice plan)

d. Drawing of building design (picture of the situation, view of the cut, septic tank and infiltration well) signed by the person in charge of the drawing

e. Structural calculations for buildings with two or more floors signed by the person in charge of the structure;

f. AMDAL/UKL/UPL recommendations specifically for development activities that have an impact on the environment in accordance with statutory provisions;

g. Photocopy of proof of payment and SPPT last year and showing the original.

As for the management procedure, the applicant fills in a written application form for a building permit stamped on paper with a temple stamp of Rp. 10000 that is submitted to the Regent, through the Head of the Integrated Licensing Service Office by attaching the requirements. The settlement period is 10 (ten) days. A one-time fee is also determined according to the building's area, length, and height, including the type of building. Researchers' initial data are on average IMB management after the building has been built, except for buildings categorized as commercial type buildings and public facility buildings or government buildings. This indicates that the government has not effectively implemented the regulation of Regional regulation No.7 of 2015.

Regional regulation No.7 of 2015 on Buildings came into force in TTS Regency from the date of its enactment but has not been sufficiently implemented by the local government and community members in the So'e city, TTS Regency. Initial data obtained by researchers shows that many privately owned buildings do not take care of the IMB. With the latest system that must take care of building permits through an online system, this cannot be realized because many conditions are challenging to obtain, for example, the building must already have an image such as a foundation, walls or retaining, roof, complete with a budget plan or required costs in constructing the building to be approved by the Public Housing and Public Works Service in each district/city. Of course, this will also be difficult for citizens to reach.

Table 1. Types and number of buildings that have taken IMB

\begin{tabular}{|c|c|c|c|c|c|}
\hline \multirow{2}{*}{\multicolumn{3}{|c|}{ Type of IMB }} & \multicolumn{3}{|c|}{ Number of Building Permits/Year } \\
\hline & & & \multirow[t]{2}{*}{2016} & \multirow[t]{2}{*}{2017} & \multirow[t]{2}{*}{2018} \\
\hline A & $\mathrm{Re}$ & dential home & & & \\
\hline & 1. & Permanent Building & 31 & 26 & 14 \\
\hline & 2. & Semi-Permanent & 5 & - & - \\
\hline & 3. & Permanent Fence & - & - & - \\
\hline $\mathrm{B}$ & \multicolumn{2}{|c|}{ Commercial Services } & & & \\
\hline & 1. & Permanent Building & 36 & 16 & 24 \\
\hline & 2. & Skyscraper & 4 & 2 & 4 \\
\hline & 3. & Semi-Permanent & 4 & 2 & - \\
\hline & 4. & Tower & 4 & 4 & 4 \\
\hline & 5. & Permanent Billboard & - & - & - \\
\hline $\mathrm{C}$ & \multicolumn{2}{|c|}{ Government buildings/public facilities } & 3 & 4 & 1 \\
\hline $\mathrm{D}$ & \multicolumn{2}{|r|}{$\begin{array}{l}\text { Change and increase the building area for commercial services, } \\
\text { government buildings and public facilities }\end{array}$} & - & - & - \\
\hline \multicolumn{3}{|c|}{$\operatorname{Sum} A+B+C+D$} & 97 & 58 & 47 \\
\hline
\end{tabular}

Data source: PMPTSP Office, TTS, 2020

From the data in Table 1 above, every year there is always an IMB issued by the local government of TTS Regency. However, it is not yet balanced with the population of the number of buildings that are scattered in all sub-districts and villages in the District of So'e City. Even though the residents in the city should be more obedient to take care of the IMB, what happened was not that many residents, both individually and in legal form, rushed to apply for the IMB.

Data as adjusted in Table 1 above average buildings have been built after a few years. When collecting preliminary data, the information obtained by researchers was that a resident of So'e was 
rushing to take care of the IMB for his shophouse because that person intended to apply for a loan from a bank in large numbers and proof of an IMB was the main requirement for obtaining a loan. Therefore, most people in So'e City want to take care of an IMB only because they have an intention to make a bank loan or for other needs, or just obey the rules or conditions of a Bank Loan and not because they are obedient to Regional regulation No.7 of 2015 article 54 regarding Permits to Build Buildings.

The calculation of the IMB levy rate is adjusted to the area of the building to be built. The results of the author's observations show that on average, IMB applicants, both personal and legal entities, are subject to fines when processing the IMB because the building managed by the IMB has been completed so that the building owner is only trying to obtain an IMB because there are other opportunities when the building has an IMB such as getting a capital loan business of a particular bank. This means that the applicant takes care of the IMB not because there is an effort from the government to enforce Regional regulation No.7 of 2015 concerning Buildings, or there is socialization from the government regarding the issue of government firmness or an appeal from the government so that citizens must hurry up to take care of the IMB.

The problem of community members not taking care of the IMB is not an inhibiting factor because the awareness of the community towards the importance of the IMB is only due to the opportunity of an offer from another party with the obligatory condition of having a business building or permanently individually or as a group or legal entity that has an IMB, and makes it easier take care of a service company business license. But, of course, intensive communication between the government on the importance of the IMB management is an inhibiting factor.

The implementation of the TTS Regency local government policy regarding buildings in So'e City, in this case, the building permit aims to ensure that the buildings built by the community are orderly and do not violate existing rules, as well as bring comfort to the community around the implementation of the TTS Regency local government policies This should pay attention to every policy made both topdown and bottom-up policies and government activities carried out to the maximum extent possible for the community where the government already has to know the aims and objectives of the policies it makes, and ensure that it does not harm the community and utilize existing resources. . The resources that exist in each government agency dealing with the IMB problem are inadequate or insufficient so that public services do not extra in serving the community.

If we look at the existing circumstances, the authors observed that the facilities and infrastructure provided by the government are not sufficient to serve the people who will take care of the IMB problem in So'e City. IMB given by the Head of Region to building owners for new buildings, changes, expands, reduces, and maintains buildings in accordance with applicable administrative and technical requirements. In accordance with the SOP of the TTS Regency Licensing and Investment Service, officials who examine an IMB application include:

a. Technical personnel determine the GSB/BSP mark at the time of construction;

b. The technical personnel will inspect the completeness of the drawing as well as check the applicable construction rules in accordance with the applicable provisions as well as examine the results of the construction calculations made;

c. The technical personnel will also inspect the implementation of the building at a certain period during the construction process as well as a final inspection at the completion of the construction;

d. Especially for buildings with two floors and so on, the Technical Team will conduct field sampling/field surveys.

Meanwhile, the population of So'e city continues to increase every year, not to mention the increase in the number of families both due to marriage and genealogy formation which continues to increase. Hence, it is necessary to have a comprehensive arrangement of residential space so that it remains organized according to the designation and utilization of regional space in So'e city. The regulations that support levies on IMB management in So'e city are the same as the regulations that apply to TTS 
Regency, which include

a. TTS Regent Regulation Number 9 of 2006 concerning Standards and Procedures for Manuscript Issuance, Manuscript Entry Process and Direct Communication Scope of TTS Regency Government Apparatus;

b. TTS Regent Regulation Number 6A of 2008 concerning Transfer of Handling of Licensing Types and Delegation of Authority for Signing Types of Permits;

c. TTS Regent Regulation Number 25 of 2008 concerning Main Duties and Functions of the TTS Regency settlement and spatial planning office;

d. TTS Regent Regulation Number 45 of 2008 concerning the main tasks and functions of the TTS Regency integrated licensing service office.

Development in the area of So'e City, which is increasingly advanced, has made developments in development increasingly increase; urban areas continue to progress from time to time, considering that cities are strategic places for various special activities related to the economy. The consequence that arises is that the rapid population growth rate creates space to accommodate and support all the activities of its population. The increasing need for space, the government is required to be able to control so that it remains in accordance with and in accordance with the established spatial plan.

So'e City recently experiences very rapid growth in the development of various sectors, especially in the sustainable development sector, such as office buildings, shops and housing and other buildings. This makes the City of So'e very densely populated with buildings so that some points of development are very rapidly developing, such as the route to the city terminal and the road to the market which is also crowded with buildings that may now be called the downtown area, because there are so many developments that are taking place. And there is also ongoing development and such as on the outskirts of the main road and near the office is experiencing rapid development. This will be the center of government for the capital city of TTS Regency; therefore, there will be a lot of development being made.

The TTS Regency Government-issued Regional regulation No.7 of 2015 concerning Buildings, which aims to regulate existing developments in the TTS area and including the City of So'e, regulating citizens to take care of Building Construction Permits (IMB) because this is a means of licensing in order to establish/changing buildings that can be used as a standard for building adjustment that can protect the safety of the community and the surrounding environment. In addition, the IMB can also be used as a legal guarantee to the community for building ownership. So, the government issued a Regional Regulation on development issues, namely "TTS Regency Regional regulation Number 7 of 2015 concerning Buildings in TTS Regency". The local government of TTS Regency with the aim of making the development carried out by the community more orderly made this regional regulation.

The contents of the regional regulation are first, (1) Building Construction Permit, hereinafter referred to as IMB, is a permit granted by the Regional Government to building owners to build new, change, expand, reduce or maintain buildings in accordance with applicable administrative and technical requirements. ; (2) Application for Building Construction Permit is an application made by a building owner to the TTS Regency government to obtain a building construction permit; (3) Every individual/entity erecting a building is obliged to have an IMB from the Regional Government of TTS Regency, except for a special function building. (4) IMB is a proof letter from the City Government that the building owner can erect the building according to the building technical plan that the City Government has approved; (5) The Regent issues a building construction permit for the following activities: (a) construction of new buildings and building infrastructure; (b) Rehabilitation/renovation of buildings and building infrastructure, including repair/maintenance, alteration, expansion/reduction; and (c) preservation/restoration; (6) Any moderate rehabilitation and severe rehabilitation as well as renovation of buildings and/or building infrastructure with a change in function of the building must again have a new IMB. (7). IMB is part of the requirements for public utility services; (8) Every building that does not meet the requirements as stated in the IMB must be dismantled or made adjustments so that it meets the provisions in the IMB. 
Many phenomena occur in So'e City, such as the number of buildings standing without permits due to several factors, such as the length of the process of issuing IMB from related agencies, in which the IMB management is not focused on just one service, ignoring several agencies that take care of this IMB, and taken from one of the newspapers in his explanation "The Head of the PMPTSP TTS Regency, Musa Benu, said that there were 92 IMB files that were issued after the building was built. This is certainly an irony for development in So'e City; because the construction is carried out without obtaining a permit first, and of course will have an impact on the environment. "(Some of them) have received the official building plan certificate, there is no IMB, they have already built it and that is wrong, they should have finished the permit first and then started to build it," they should have forwarded their statement to BLHD. At BLHD, a Statement of Environmental Management and Monitoring (SPPL) will be made. Just take care of the IMB. After the licensing is complete, then start building. Do not allow permits to be processed. Construction is already underway, "he said.

Based on the phenomenon that occurs, researchers are interested in conducting research on this problem with a study entitled "Implementation of Building Permit Policy based on the Regional Regulation of TTS No.7 of 2015 concerning Buildings in So'e city, TTS Regency"

\section{Literature review}

\subsection{Public policy}

Public policy is a decision that is intended to overcome problems that arise in certain activities carried out by government agencies in government administration. Judging from the hierarchy, public policies can be national, regional, and local, such as laws, government regulations, presidential regulations, ministerial regulations, regional/provincial government regulations, governor decrees, regency/city regional regulations, and district/mayor decrees. Thus, in terminology, the definition of public policy (public policy) turns out to be a lot depending on which angle we interpret it.

Easton defines public policy as the authoritative allocation of values for the whole society or as the allocation of values forcibly to all members of society. Laswell and Kaplan also define public policy as a projected program of goals, values and practice or a program of achieving goals, values in directed practices. Pressman and Widavsky, as quoted by Budi Winarno (2002: 17), define public policy as a hypothesis, which contains initial conditions and predictable consequences.

Robert Eyestone, as quoted by Agustino (2008: 6) defines public policy as the relationship between government units and their environment. According to Riant Nugroho (2011: 143) there are two characteristics of public policy, namely:

a. Public policy is something that is easy to understand because it means things that are done to achieve national goals.

b. Public policy is something that is easily measured because the measurement is clear because of the progress towards achieving the goals that have been taken.

Woll, as quoted by Tangkilisan (2003: 2), states that public policy is a number of government activities to solve problems in the community, either directly or through institutions that affect people's lives. James E. Anderson, as quoted by Islamy (2009: 17), states that public policy is "a purposive course of action followed by an actor or set of actors in dealing with a problem or matter of concern" (a series of actions that have a specific purpose which is followed. and implemented by an actor or a group of actors in order to solve a particular problem). From the definition of the experts above, it can be concluded that public policy is a series of policy decisions taken by a person or group of people to achieve certain goals in society.

\subsection{Definition of public policy implementation}

Van Meter and Van Horn in Budi Winarno (2005: 102) define the implementation of public policies as: "Actions taken by public organizations that are directed to achieve the goals set out in previous decisions. These actions include attempts to convert decisions into operational actions within a certain 
period of time as well as in order to continue efforts to achieve major and minor changes that are implemented by policy decisions".

The policy implementation stage will not start until the policy formulation's goals and objectives are determined. Thus, the policy implementation stage occurs only after the law is enacted and funds are made available to finance policy implementation. Implementation comes from the verb "to implement". According to Webster's Dictionary (in Tachan, 2008: 29), the word to implement comes from the Latin "implementum" from the origin of the words "impere" and "plere". The word "impere" means "to fill up", to fill in ", which means to fill completely, to complete, while "plere "means" to fill. If the definition of implementation above is coupled with public policy, then the word public policy implementation can be interpreted as the activity of completing or implementing a public policy that has been determined/approved by the use of means (tools) to achieve policy objectives.

Thus, in the public policy process, the implementation of public policy is a stage that is practical and distinguished from policy formulation, which can be seen as a stage that is a priority. Anderson (in Tachan, 2008: 30) argues that "policy implementation is applying the policy by the government's administrative machinery to the problem". Then Edward III (in Tachan, 2008: 30) stated that: "policy implementation, .. is the stage of the policymaking between the establishment of a policy...an and the consequences of the policy for the people whom it affects". Meanwhile, Grindle (in Tachan, 2008: 30) suggests that "implementation-a general process of administrative action that can be investigated at a specific program level".

From the description above, it is obtained an illustration that public policy implementation is a process of administrative activities carried out after the policy is stipulated/approved. This activity lies between policy formulation and policy evaluation. Policy implementation contains top-down logic, which means reducing/interpreting alternatives that are still abstract or macro to be alternatives that are concrete or micro in nature. Meanwhile, policy formulation contains bottom-up logic, in the sense that this process begins with mapping public needs or accommodating environmental demands followed by finding and selecting alternative solutions, then it is proposed to be determined.

\subsection{Factors that influence public policy implementation}

In analyzing the implementation process of the building permit service policy in So'e city, it is known that the program's success can be studied from two different perspectives, namely from the point of view of process (implementation) and results (outcomes). The first perspective emphasizes consistency between program and policy implementation with policy guidelines. According to this perspective, a government program is said to be successful if the program's implementation is in accordance with the predetermined policy guidelines. A program can be considered successful from the review of the outcomes if the program produces the desired impact (Dwiyanto, 1999: 87).

Edward III (1984) proposes 4 (four) variables that greatly influence the success of policy implementation, namely:

a. Communication is a means to disseminate information, both from top to bottom and from bottom to top. In order to avoid distortion of information conveyed by superiors to subordinates, it is necessary to have a timeline and the delivery of information must be clear, and it requires accuracy and consistency in conveying information.

b. Resources in policy implementation play an important role, because policy implementation will not be effective if the supporting resources are not available. Included in these sources are:

1. The staffs are relatively sufficient in number and have the expertise and skills to implement policies.

2. Sufficient or relevant information for implementation purposes.

3. Support from the environment for the success of policy implementation

4. The authority of the implementor to implement policies. 
c. Dispotition or attitude, which is related to how the attitude of the implementer in supporting a policy implementation. Often the implementers are willing to take the initiative in order to achieve policy, depending on the extent of authority they have.

d. Bureaucratic structure (bureaucratic structure), namely a policy often involves several institutions or organizations in the implementation process, so that effective coordination between related institutions is needed to support successful implementation.

When connected with the writing of this Thesis, the causal factors that can be treated through a policy (actionable causes) are the dependent variable, in this case, what is meant is the process of implementing a building permit service policy, where the factors This will be seen in its implementation which is adjusted to the stipulated legislation so that in its implementation it will be seen that the stages of the process are carried out towards the goals and benefits of the policy program achieved. While the factors that influence the process of implementing the building permit service policy are independent variables obtained from the model developed by Sabaiter and Masmanian (in Wahab, 2011: 65) which identifies the factors that influence the achievement of formal goals of the entire policy implementation process, namely:

a. Characteristics of the problem such as the availability of technology and technical theory, the diversity of behavior of the target group, the process of the target group compared to the population, the desired behavior space.

b. The ability of the policy to structure the implementation process, such as clarity and consistency of objectives, causal theory that marks, sufficient financial resources, implementing organization integration, executive board, recruitment of executive officers, formal access to outsiders.

c. Non-regulatory factors such as socio-economic conditions, public support, attitudes and resources, support for authority, commitment and ability of executing officials.

Of the various indicators included in these variables, based on considerations of conditions in the field, they are sequenced into several variables which are considered to be the closest to explaining the problems in the policy implementation process. In the constellation, the dominant factors affecting the policy implementation process are policy content factors in the policy context such as the availability of resources, characteristics of policy implementation, administrative and organizational characteristics, as well as time aspects such as service delivery and compliance, in addition to certain events or incidents during policy implementation. In addition, it affects the assumption of continuity, both the characteristics of policy activity, administration and implementers in carrying out the objectives of the policy as a mandate that must be accounted.

In this regard, the five variables can be assumed to be factors that can influence the successful implementation of policies in the field. Any program essentially needs implementers who have a strong desire to develop new work implementation rules and procedures and are willing to work hard to enforce them in the face of resistance from target groups and government officials who are reluctant to implement changes. In principle, there are several ways that legislators/regulations can take to ensure that implementing officials have the necessary agreement to achieve the objectives. The responsibility for implementation can be assigned to bodies whose policy orientation aligns with the law and is willing to put the new program first. Such procedures are primarily implemented when a new body is explicitly formed to enforce the law, to make the program a priority, the new posts will open the door to supporters of the law. Second: implementation can also be assigned to material existing ones who view the new assignment in line with the orientation it has had and is currently looking for new programs.

Based on the above opinion, it can be concluded that policy implementation is in principle not only limited to the process of implementing a policy but also covers the actions or behavior of individuals, government and private groups, as well as administrative bodies or bureaucratic units that are responsible for implementing the program in achieving its goals. However, it also looks at the various political, social, and economic forces that have an influence on the goals to be achieved. Thus, policy implementation is intended to understand what happens after a program is formulated and what 
impacts arise from that policy program. In addition, policy implementation is not only related to administrative issues, but also examines environmental factors that influence the policy implementation process.

\section{Edward III policy implementation model}

According to Edward III, in Agustino, four variables determine the success of implementing a policy, namely communication, resources, disposition, and bureaucratic structure. The four of them can be explained as follows:

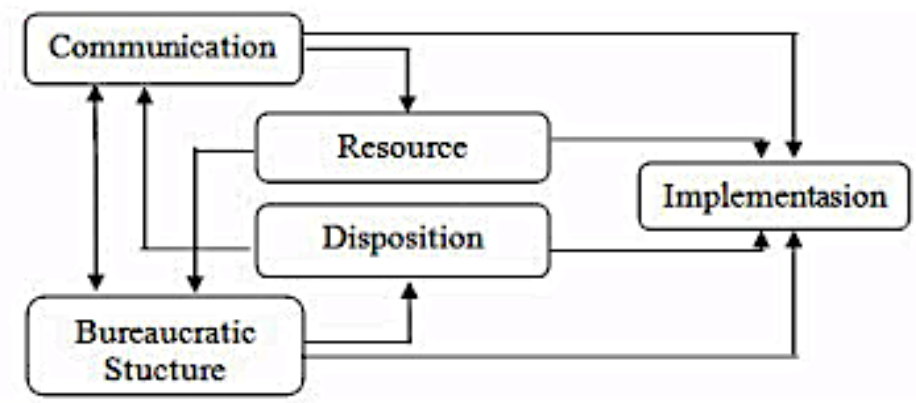

Figure 1. Model of direct an indirect impact on implementation approach

(George. Edward III, 1984 in Agustino, 2008: 150)

Based on the description in the Direct An Indirect Impact On Implementation (George. Edward III) approach model, it can be explained, among others:

a. Communication. Communication is important because knowledge of what they will do can work if communication goes well between policymakers and implementers so that any policy decisions and implementation regulations must be transmitted to the appropriate personnel department. There are three indicators in measuring the success of communication, namely:

1) Transmission, good communication channels will produce a good implementation, too, by avoiding miscommunication (misunderstanding).

2) Clarity, communication received by policy implementers must be clear (street levelbureaucrats) and should not be confused (not ambiguous in meaning).

3) Consistency, the instructions given in implementing a communication must be consistent and clear to be implemented or carried out.

b. The second variable or factor that affects the successful implementation of a policy is resources, which consist of:

1) Staff, as the main resource in policy implementation. Increasing the number of staff and implementing it is not sufficient, but it is necessary to have sufficient staff with expertise and competence (ability) to implement policies.

2) Information, namely the first information relating to how to implement policies. And secondly, information regarding compliance data from the implementers to government regulations and regulations.

3) Authority, is the authority or legitimacy for the implementers in implementing policies that are determined politically.

4) Facilities and physical facilities are also important factors in policy implementation. Implementers may have sufficient staff, understand what to do, and have the authority to carry out their duties, but without supporting facilities the implementation of the policy will not be successful.

c. The third variable is disposition. Disposition is the attitude of policy implementers to have the ability to implement. The thing that needs to be considered in this variable is the appointment of personnel, namely in selecting and appointment of personnel who implement policies, people who are dedicated to the policies that have been set, more specifically in the interests of the citizens. Incentives, namely by adding certain benefits or costs that might be a driving factor for policy implementers to carry out orders well. 
d. The fourth variable is the bureaucratic structure. Such a complex policy demands the cooperation of many people, when the bureaucratic structure is not conducive to the available policies, this will make the use of various existing resources ineffective and Edward III in Leo Agustino (2008: 153) can do the Standard Operating Procedures (SOPs) and performing fragmentation. Standard Operating Procedures (SOPs) are routine activities carried out on a daily basis in accordance with established standards (or the minimum required by residents). Meanwhile, the implementation of fragmentation is an effort to distribute the responsibility for employee activities among several work units. It can be concluded that in every policy implementation, there will be a series of implementation activities of the policy involving existing resources, namely the facilities and infrastructure to be implemented to the community in order to achieve the goals desired by policymakers.

\section{Research methodology}

This study uses a methodology with a qualitative approach. The research location includes all subdistricts/villages in the District of So'e City, South Timor Tengah regency. There are 36 informants. Data collection techniques and procedures in this study were interviews, observation and documentation. Activities in data analysis use the theory of Milles and Huberman, 1984 in Sugiyono, (2014: 335) the stages of data collection, data reduction, data display and conclusion drawing/verification (in Sugiyono, 2014: 335), namely Data Collection, Analyzing Data (Data Reduction), Data Presentation (Data Display), Conclusion Drawing and Verification (Conclusion Drawing/Verification). Validity testing is based on ensuring whether the research results are accurate from the point of view of researchers, participants or readers in general (Sugiyono, 2014: 121) includes; Trust (Credibility), Transferability (Transferability), Dependability, Certainty (Confirmability).

\section{Results of research and discussion}

The factors that influence the implementation of the Building Permit (IMB) service policy in So'e city, South Central Timor Regency are analyzed based on the Direct An Indirect Impact On Implementation (George. Edward III) model, namely communication, resources, disposition and bureaucratic structures will be discussed on the results of the research and discussion as follows:

a. Communication

Communication indicates that each policy will be implemented well if there is effective communication between policy program implementers and target groups. Communication is a powerful mechanism for implementing public policy. The better the coordination and communication between the parties involved in an implementation process, the fewer errors will occur. Thus, communication is critical to achieving the objectives of implementing the Building Construction Permit (IMB) policy at the Investment Service and One-Stop Integrated Services in South Timor Tengah regency. Based on document data obtained in the process of implementing the Building Permit policy in So'e city, So'e city, South Central Timor Regency, that in line with the rapid development carried out by the government and the people of South Central Timor Regency, there are several provisions in Regional Regulation 7 of 2015 concerning Buildings, thus creating consequences for the Government of South Timor Tengah regency to control, organize and develop in an orderly, directed and integrated manner in the future so that arrangements are needed in terms of building construction. Ineffective socialization to the community so that many people only know but do not understand the importance of building permits according to TTS Regional Regulation No. 7/2015. Furthermore, the communication carried out by the Public Housing and Settlement Areas of South Timor Tengah regency related to Building Construction Permit services delegation of authority has been given to the Investment Service and One Stop Integrated Services. Communication to the leadership (head of service) only reports activities in the management process and has been completed in the IMB process because there has been a delegation of authority from the Regent to the Head of Service with the TTS Regent Regulation Number 9 of 2019 for coordination to staff by providing direction and instructions according to the SOP and main duties and functions of each staff. It can be stated 
that communication has been effective in implementing the Building Construction Permit (IMB) service program as the decision-maker who knows what they will do so that the duties and responsibilities they will do can run well.

Meanwhile, the communication that exists between program implementers and target groups, including the community in South Timor Tengah regency in general and especially applicants for IMB, is still ineffective because the public does not know the contents of the TTS Regional Regulation Number 7 of 2015, which regulates the IMB process and the importance of buildings that have an IMB. Based on the research results in terms of communication in the implementation of the building permit (IMB) service policy in South Central Timor Regency, communication has not been effectively established within the scope of implementing the Building Construction Permit (IMB) service program as the decisionmaker knowing what they will do so that the duties and responsibilities answer that they will do can work well. Meanwhile, the communication that exists between program implementers and target groups, including the people of South Timor Tengah regency, is generally still ineffective due to the socialization of local regulations regarding building permits in the South Central Timor District. The function of coordination and communication between organizations can be seen as part of the glue, alignment, or integration of the work implementation of each work unit so that it becomes a unified work mechanism that is cohesive and directed towards a predetermined goal and target. Besides that, various problems and obstacles in providing services to the community can be identified through communication, and solutions can then be formulated. Thus, the prospect of effective policy implementation is primarily determined by the communication of policy implementers accurately and consistently (accuracy and consistency). This is in line with the opinion of Hogwood and Gunn in Wahab (2002: 71), which states that in order to implement the policy perfectly (perfect implementation), certain requirements for communication and perfect coordination are needed.

b. Resource

Every policy must be supported by adequate resources, both human resources and financial resources. The success of the policy implementation process is highly dependent on the ability to utilize available resources. Humans are the most important resource in determining a successful implementation process. The stages of the whole implementation process require qualified human resources according to work required by the politically determined policies. But when the competency of these resources is zero, the performance of public policies is very difficult to expect. Based on the document data obtained, the number of State Civil Servants (ASN) in the Licensing Service Sector is 9 (nine) people with 5 (five) undergraduate education levels, 4 (four) high school students. In particular, in the Licensing service section, the number of State Civil Servants (ASN) is 4 (four) people with 2 (two) undergraduate education levels and 2 (two) high school students.

Meanwhile, government financial resources are very supportive with every year there are several programs, one of which is the Acceleration of Making Building Permits (IMB). Based on the results of field observations, it was found that human resources in implementing the policy for building construction permits (IMB) services were inadequate due to the lack of staff in the Licensing and Spatial Planning Sector so that IMB services were not optimal. In addition, the permit issuance process must go through predetermined procedures so that obtaining a Building Permit requires a long process because it goes through the steps determined by the One-Stop Investment and Integrated Service Agency (DPMPTSP). The results showed that educational background and expertise are very influential in improving employee performance. Thus, human resources in implementing policies and in carrying out their duties and responsibilities must have the expertise and ability to carry out the duties and responsibilities of the leadership. And besides that, in human resources, there must be accuracy and appropriateness between the number of staff needed and the expertise they have in accordance with the job duties they handle. Apart from human resources, there are 
financial resources and equipment resources needed to finance the operationalization of policy implementation. However, the limited equipment available causes the quality of building permit (IMB) services that must be given to the community is also limited. The factors that become obstacles in the IMB service policy are as follows:

1) Limited human resources, namely people who are experts in drawing buildings

2) Buildings that are not in accordance with the spatial pattern so that the building is not properly organized and buildings that violate the Building Grouping Line (GSB)

3) Knowledge/understanding with the community regarding Regional Regulation Number 7 of 2015 concerning Buildings in Chapter. VI concerning Building Construction Permit (IMB).

The success of the policy implementation process is highly dependent on the ability to utilize available resources. Humans are the most important resource in determining a successful implementation process. Certain stages of the entire implementation process, according to the presence of qualified human resources in accordance with the work required by policies that have been determined apolitically. But when the competence and capabilities of these resources are nil, then the performance of public policies is very difficult to expect. In line with what Van Mater and Van Horn put forward in Subarsono (2011: 100), it is stated that policy implementation needs the support of human resources (human resources) and the support of non-human resources (non-human resources). The success of policy implementation depends on the ability to use available resources. Humans are the most important resource in determining the success of policy implementation. Each stage of implementation demands quality human resources according to work indicated by policies set apolitically. Apart from human resources, financial resources and time are important calculations in the success of policy implementation. Furthermore, Van Mater and Van Horn (in Budiharto, 2010: 33) argue that policy resources are no less important than communication. These policy resources must also be available in order to facilitate the administration of implementing a policy. These resources consist of funds or other incentives that can facilitate the implementation of a policy. Lack of or limited funds or other incentives in policy implementation is a major contribution to the failure of policy implementation. Resources referred in this case human resources, financial resources and equipment resources. In terms of human resources are still lacking and limited, besides that there is no accuracy and appropriateness between the number of staff needed and the expertise they have in accordance with the job duties they handle. Funding/financial resources are not effective enough for programs and activities concerning Building Construction Permits (IMB). Equipment resources are still limited to support the operationalization of the implementation of the Building Construction Permit (IMB) service policy. Disposition and bureaucracy are also considered ineffective.

c. Disposition

Dispositions are characteristics that stick closely to the policy/program implementer. Disposition is defined as the attitude of the implementers to implement policies. Therefore, if the implementation of the building permit policy in South Central Timor District is to be successful, the policy implementers know what to do and must also have the ability and willingness to implement the policy democratically, enthusiastically and enthusiastically responsively to the community. The attitude of the executor referred to in this research refers to the attitude of transparency in carrying out its duties and functions in the implementation of Building Construction Permits (IMB). Based on document data obtained in the Strategic Plan of the Investment Service and One-Stop Integrated Service of South Timor Tengah regency, data is obtained in the implementation of building construction permits services, each employee works in accordance with the main tasks and functions and section descriptions of business and non-business licensing services with the division of tasks and responsibilities clear, apart from that in achieving the performance of the One-Stop Investment Service and One Stop Services in the Licensing and Non-Licensing Implementation Sector, namely the service of the community in obtaining business permits in 
accordance with Regional Regulation Number 7 of 2015 concerning Regency/City Regional Building along with detailed plans to achieve achievement indicators number 100 . Then based on the results of field observations regarding building construction permit (IMB) services, there is already a willingness to provide optimal service by providing effective services to the applicant community. The direct disposition is given to the staff according to their respective main duties and functions because the IMB management flow is that the IMB applicant submits the file to the PMPTSP Office then the complete file is submitted to the PRKP Office to review the applicant's location for technical inspection and then a recommendation is issued back to the PMPTSP Office to calculate retribution The IMB then issues a recommendation for the applicant to pay the IMB levy so that the permit can be issued. The results show that the implementers already know what they have to do and implement the policy according to their respective main duties and functions, and they have the will to implement the policy. According to Edward III in Winarno (2002: 142-143) suggests "tendencies or dispositions are one of the factors that have important consequences for effective policy implementation". Suppose the implementers have a positive tendency or attitude or support for policy implementation. In that case, there is a high probability that the policy implementation will be carried out in accordance with the initial decision. This is in accordance with the theory put forward by Edward III that this disposition is defined as the attitude of the implementers to implement policies.

In implementing policies, according to Edward III, if they want to be successful effectively and efficiently, implementers must not only know what they are doing and have the ability to implement the policy, but they must also have the will to implement the policy. According to Van Metter and Van Horn in Agustino (2008: 45): "The attitude of acceptance or rejection of policy implementation agents greatly affects the success or failure of public policy implementation. This is possible because the policies implemented are not the result of the formulation of local residents who are very familiar with the problems and problems they feel. However, public policies are usually top-down in nature, which makes it possible for decision-makers not to know or even to be able to touch the needs, wants or problems that must be resolved. According to the researcher, what has happened in the building permit service in South Timor Tengah regency is that the implementor's response to policies is quite good, which is related to the willingness of the implementors to implement public policies. In terms of conditions, namely, the understanding of the policies determined by the implementor has a fairly good disposition. Implementing the IMB service policy in South Timor Tengah regency in carrying out policies well is like what policymakers want. The widespread and deep acceptance of the standards and policy objectives among those responsible for implementing these policies is an excellent potential for the successful implementation of policies (Kaufman in Van Mater and Van Horn, 1974). In the end, the intensity of the disposition of the implementers (Implementors) can affect the implementation (performance) of the policy. The lack or limited intensity of this disposition will lead to failure of policy implementation.

d. Bureaucratic Structure

The bureaucratic structure is important in policy implementation (mechanism and organizational structure for executing/dividing tasks and responsibilities). Although the resources for implementing a policy are sufficient and implementers know what and how to do it, and they have the desire to do it, the implementation may not be effective because of the inefficiency of the existing bureaucratic structure. Such a complex policy requires the cooperation of many people, the bureaucracy as the implementer of a policy must be able to support policies that have been decided politically by means of good coordination. Based on the data obtained, the strategic plan of the Modan Planting Service and One Stop Integrated Service, South Central Timor Regency, describing the main tasks and functions of each employee. In addition, it is supported by the regional regulation of South Central Timor Regency Number 7 of 2015 concerning Buildings and is described in more detail in Chapter VI regarding Building Permits. South Central Timor Regent Regulation Number 32 of 2017 
concerning Technical Guidelines for the Implementation of Regional Regulation of South Central Timor Regency Number 7 of 2015 concerning Buildings, Regulation of the Regent of South Central Timor Number 9 of 2019 concerning Delegation of Authority for Signing Permits and Non-Licensing of Investment to the Head of the Investment Service One Stop Integrated Capital and Services, South Timor Tengah regency. Based on observations made by researchers in the field, it was found that information on the commitment of the implementing agency for the Building Construction Permit (IMB) service in implementing policies/programs was in accordance with applicable standards and mechanisms so that the implementer understood and understood the main duties, functions and responsibilities of each individual and institutional.

The results of the research and discussion above can be concluded that the Building Permit (IMB) is one of the policies aimed at controlling and supervising building construction, namely the creation of an orderly building structure and meeting building engineering and aesthetic standards, so that it is safe, comfortable, healthy and has economic value to be used as a residence or to carry out economic and socio-cultural activities for residents or users. The successful implementation of a public policy can be measured from the process of achieving outcomes, namely whether or not the objectives to be achieved are achieved based on the interests of the target group, types of benefits, the degree of change desired, location of decision making, program implementation and the resources involved. The implementation of a building permit itself provides many benefits for development, both in the interests of the government and the community building permit, such as the existence of a building permit that can show the legality or legality of buildings owned by the community, besides making it easier for the community to use it for their daily needs. In addition, for the applicant community, the building permit provides the benefit of a sense of security, beauty and harmony of the building to its environment as well as an added value to the building itself.

The added value includes, among others, the price of a building which will increase by itself, as a condition for applying for a mortgage (credit with land and building guarantees), as well as legal certainty for the building itself. Building Construction Permits are intended to optimize the arrangement, supervision and control of building construction activities carried out by the community in line with the increasingly developing and advanced life. The implementation of building construction permits (IMB) successfully and efficiently will bring benefits to the interests of individuals, communities and the government as managers and controllers in spatial planning so that in implementing Building Construction Permits it is not merely rules that force the community but will constitute a basic requirement in the construction and ownership of buildings. Based on the observations made, it shows that there are several phenomena of problems or obstacles in the context of implementing the Building Construction Permit in the So'e city, South Central Timor Regency, including:

1) There are still community members and business owners who do not understand the procedures in IMB management

2) Resource capabilities are still limited

3) Socialization has not been carried out optimally

4) The number of personnel/employees is still insufficient

5) The professionalism of employees or officers has not been seen

6) Supporting facilities, equipment and facilities are still limited

7) Coordination with other related agencies has not been effective, and other obstacles are technical in nature.

The results of the research show that DPMPTSP, which has the authority in terms of bureaucratic services for Building Construction Permits while technical matters are taken over by the Public Housing and Settlement Area Services and as the implementer of the Building Construction Permit (IMB) service, already knows, understands and understands the main tasks, functions and responsibilities each - both individually and institutionally. In 
addition, the PRKP is active in supervising and controlling buildings that violate the Building Construction Permit (IMB). Although the resources for implementing a policy are sufficient and implementers know what and how to do it, and they have the desire to do it, policy implementation may still be ineffective due to the inefficiency of the existing bureaucratic structure. Policies are so complex according to the cooperation of many people, the bureaucracy as the implementer of a policy must be able to support policies that have been decided politically by way of good coordination. In the process of implementing the Building Construction Permit (IMB) policy, it can be seen that the supporting factors in the Building Construction Permit (IMB) policy are as follows:

1) South Central Timor Regency Regulation Number 7 of 2015 concerning Buildings

2) South Central Timor Regent Regulation Number 32 of 2017 concerning Technical Guidelines for the Implementation of Regional Regulation of the South Central Timor Regency Number 7 of 2015 concerning Buildings

3) South Central Timor Regent Regulation Number 9 of 2019 concerning Delegation of Authority for Signing Permits and Non-Licensing, Investment to the Head of the Investment Service and One-Stop Integrated Services of the South Central Timor District.

The implementation of complex policies requires cooperation from many parties. When the bureaucratic structure is not conducive to implementing a policy, this will cause ineffectiveness and hinder the implementation of the policy. Based on the explanation above, understanding the structure of the bureaucracy is a fundamental factor for assessing the implementation of public policies. According to Edwars III in Winarno (2005: 150) there are two main characteristics of the bureaucracy, namely: "standard operating procedure (SOP) and fragmentation. In implementing the policy for building construction services in South Timor Tengah regency, SOPs are already available so that IMB employees or implementers of IMB service policies carry out routine activities every day according to predetermined standards.

In terms of fragmentation, it is in the form of efforts to distribute the responsibilities of activities and activities of employees among several units. In the DPMPTSP strategic plan, it is clear that each field's main duties and functions are clear. In the process of implementing the building permit (IMB) service policy in South Central Timor District, it is seen from 4 indicators, namely: Communication, Resources, Disposition and Bureaucracy. Communication is the process of building a building permit (IMB) service in the South Central Timor District within the scope of implementing the policy has been effective. However, communication between policy implementers and target groups, namely the community applying for IMB in South Timor Tengah regency, is not effective in implementing the socialization of the regional regulations of South Timor Tengah regency Buildings are more specifically related to building permits. The implementers of the IMB service policy in South Timor Tengah regency already know what they have to do and implement the policy according to their respective duties. DPMPTSP has the authority in terms of IMB services while DPRKP carries out the technical matters of the building.

\section{Conclusion}

Factors that influence the implementation of the building permit (IMB) service policy in So'e city, South Timor Tengah regency; (a) Communication in the implementation of the building permit policy in South Timor Tengah regency has not been effectively established within the scope of the building permit program implementer as the decision-maker. Socialization of Regional regulation Number 7 of 2015 concerning Buildings and more specifically regarding Building Construction Permits (IMB) carried out by program implementers and target groups in South Central Timor Regency is still ineffective, (b) Resources both human resources and financial resources is still limited. There is no accuracy and appropriateness between the number of staff needed and the expertise they have in accordance with the job duties they are handling. Funding/financial resources already exist to 
implement programs and activities regarding building permits but are not well utilized. Equipment resources are still very limited to support the operationalization of the implementation of the building construction permit (IMB) service policy. (C) The disposition in the implementation of the building permit policy is considered effective. The implementers of the building permit policy already know what they have to do and implement the policy according to their respective duties. And they want to implement these policies, but public policies are usually top-down, which makes it possible for decision-makers not to know or even unable to address the needs, desires or problems that must be resolved, (d) the One-Stop Investment and Integrated Service Agency which has the authority to in terms of bureaucratic services for Building Construction Permits. At the same time, technical matters are taken over by the Public Housing and Settlement Area Service (DPRKP) and as the implementer of the Building Construction Permit (IMB) service, they already know, understand and understand the main tasks, functions and responsibilities of each individually and institutionally.

\section{References}

Agustino, Leo. (2008). Dasar-dasar kebijakan publik. Bandung. Alfabeta

Badan Pusat Statistik Timor Tengah Selatan. (2018). Kecamatan Kota Soe dalam angka 2018. Timor Tengah Selatan. Badan Pusat Statistik.

Budiharto, Widodo. (2010). Robotika : teori + implementasi. Yogyakarta. Andi.

Dwiyanto, Agus. (1999). Evaluasi programdan kebijaksanaan pemerintah, pelatihan dan teknik manajemen kebijakan public. Jakarta: Angkatan II, UGM.

Edward III, George C (edited). (1984). Public policy implementing. JAI Press inc. London-England.

Islamy, Irfan M. (2009). Prinsip-prinsip perumusan kebijaksanaan negara, Cetakan ke-15. Jakarta. Bumi Aksara.

Nugroho, Riant. (2012). Public policy, dinamika kebijakan, analisis kebijakan, manajemen kebijakan. PT Elex Media Komputindo.

Pemerintah Daerah Kabupaten Timor Tengah Selatan. (2006). Peraturan Bupati TTS Nomor 9 Tahun 2006 tentang standar dan tata cara penerbitan naskah, proses pemasukan naskah dan ruang lingkup komunikasi langsung aparatur pemerintah Kabupaten TTS. Sekertariat Daaerah Kabupaten Timor Tengah Selatan.

Pemerintah Daerah Kabupaten Timor Tengah Selatan. (2008). Peraturan Bupati TTS Nomor 6A Tahun 2008 tentang pengalihan penanganan jenis perizinan dan pelimpahan kewenangan jenis penandatanganan izin. Sekertariat Daaerah Kabupaten Timor Tengah Selatan.

Pemerintah Daerah Kabupaten Timor Tengah Selatan. (2008). Peraturan Bupati TTS Nomor 25 Tahun 2008 tentang tugas pokok dan fungsi dinas permukiman dan tata ruang Kabupaten TTS. Sekertariat Daaerah Kabupaten Timor Tengah Selatan.

Pemerintah Daerah Kabupaten Timor Tengah Selatan. (2008). Peraturan Bupati TTS Nomor 45 Tahun 2008 tentang tugas pokok dan fungsi kantor pelayanan perizinan terpadu TTS Kabupaten. Sekertariat Daaerah Kabupaten Timor Tengah Selatan.

Pemerintah Daerah Kabupaten Timor Tengah Selatan. (2015). Peraturan Daerah Kabupaten Timor Tengah Selatan Nomor 7 Tahun 2015 tentang bangunan gudung. lembaran daerah Kabupaten Timor Tengah Selatan Tahun 2015 Nomor 7. Sekertariat Daaerah Kabupaten Timor Tengah Selatan.

Pemerintah Daerah Kabupaten Timor Tengah Selatan. (2017). Peraturan Bupati Timor Tengah Selatan Nomor 32 Tahun 2017 tentang pedoman teknis pelaksanaan peraturan daerah Kabupaten Timor Tengah Selatan Nomor 7 Tahun 2015 tentang bangunan gedung. lembaran daerah Kabupaten Timor Tengah Selatan Tahun 2017. Sekertariat Daaerah Kabupaten Timor Tengah Selatan.

Pemerintah Daerah Kabupaten Timor Tengah Selatan. (2019). Peraturan Bupati Timor Tengah Selatan Nomor 9 Tahun 2019 tentang pendelegasian kewenangan penandatanganan perizinan dan non perizinan penanaman modal kepada kepala dinas penanaman modal dan pelayanan terpadu satu pintu Kabupaten Timor Tengah Selatan. Lembaran Daerah Kabupaten Timor Tengah Selatan Tahun 2019 Nomor 10. Sekertariat Daaerah Kabupaten Timor Tengah Selatan.

Subarsono. (2011). Analisis kebijakan publik (konsep, teori dan aplikasi). Yogyakarta. Pustaka.

Sugiyono. (2014). Metode penelitian kuantitatif, kualitatif dan R\&D. Bandung. Alfabeta, 
Tachjan. (2008). Implementasi kebijakan publik. Bandung. Puslit KP2D Lamlit UMPAT.

Tangkilisan. (2003). Kebijakan publik yang membumi, konsep, strategi dan kasus. Yogyakarta. Lukman Offset dan YPAPI.

Van Meter, D.S. and Van Horn, C.E. (1974). The policy implementation process : a conceptual framework, administration and society.

Wahab, Solichin, Abdul. (2011). Analisis kebijaksanaan dari formulasi ke implemtasi kebijakan negara. Jakarta. PT Bumi Aksara.

Winarno, Budi. (2002). Teori dan proses kebijakan publik. Yokyakarta. Media Presindo.

Winarno, Budi. (2005). Kebijakan publik: teori dan proses. Yogyakarta. Media Pressindo. 